\title{
IMPLEMENTATION PROPOSAL FOR THE ASSESSMENT OF OCCUPATIONAL ACCIDENT COSTS IN TERMS OF QUALITY COSTS
}

\author{
Prof.Dr. Süleyman Yükçü, Dokuz Eylül University, Faculty of Economics and \\ Administrative Sciences, Department of Business Administration, \\ suleyman.yukcu@deu.edu.tr \\ Dr.Seçkin Gönen, Dokuz Eylül University, Faculty of Economics and \\ Administrative Sciences, Department of Business Administration, \\ seckin.gonen@deu.edu.tr
}

\begin{abstract}
Occupational accidents, whether they are work-related or not, are defined as unplanned and unforeseen incidents which cause one or more than one workers to get ill, injured or lose their lifes. The increase in occupational accidents in recent years, together with the decrease in productivity and production efficiency, has mooted direct and indirect costs for companies. Quality costs are the type of costs which arise due to the activities implemented in order to preclude possible flaws, to the planned quality tests,and to flaws that appear during the production or customer delivery processes. Quality costs are classified in British Standards 6143 as follows:
\end{abstract}
(a) Prevention Costs
(b) Appraisal Costs
(c) Internal Failure Costs
(d) External Failure Costs

As regards quality costs, occupational accidents that may produce highly excessive costs can be prevented by executing a good number of prevention activities. With the analysis of workflow processes in the established or subsequently established engine park, quality costs of those processes can be measured and evaluated in terms of occupational accidents. Despite prevention costs and appraisal costs, occupational accidents may still continue to appear in companies owing to various reasons. Those accidents may cause cessation in the production flow, or effect defective products. All these costs combined may constitute a considerable amount of internal failure costs. A company, along with internal failure, may have to endure a good number of appraisal costs and indemnities owing to workers' complaints. In this study the 
internal and external failure costs caused by a significant industrial accident which occurred during implementation will be appraised. Furthermore, costs of operating activities aimed at preventing this type of occupational accidents will be discussed and a number of proposals will be presented in respect to probable prevention costs.

\section{Key words: Occupational Accidents, Quality Costs}

\section{INTRODUCTION}

Occupational accidents are still one of the serious problems in Turkey as in many other countries. Due to occupational accidents, permanent disabilities and deaths occur and economic and work day losses emerge. In other words, occupational accidents cause negative economic loss and social problems for employers, employees and their families (Unsar and Sut, 2009;614). This problem is reinforced by statistics, which reveal worrying numbers. For example, according to the statatistical figures determined by the National Social Security Department, an occupational accident occurs in every six minutes and in every five hours, an employee loses his/her life. This fact manifests that one of the every three or four workers who tries to earn a living for the family can not make it back home from work in the evening. Data regarding occupational accidents and death cases between the years 2004-2007 were announced by the National Social Security Department. Due to this data, there has been a downward tendency in the number of occupational accidents whereas the deathly caes have an increasing trend. It is prequisite that this above-mentioned increase be carefully observed by the authorities (Ağar, 2009;82). Studies for this purpose, particularly on the issues concerning the legal changes for solutions for the deathly cases as well as providing work security have increased in number. Utilizing from the quality costs can be accepted as one of them. Occupational accidents can be prevented especially by forestalling activities with the help of laying down the firm's operational costs.

Despite the growing amount of published research about the occupational accidents and quality costs separetely, little is known about the relationship between these concepts. Taking into account the theoretical gap in the literature, the main purpose of this study is to asses occupational accident costs in terms of quality costs. The objective breaks down into these following specific goals: (1) to study examines the internal and external failure costs caused by a significant occupational accident which occured during implementation and (2) to estimate the costs of activities aimed at preventing the occupational accidents. In order to accomplish these objectives, we first carry out an exhaustive literature on occupational costs and quality cost. We then express the relationship between occupational accidents and cost of quality with the help of an actual case study. Subsequently we draw some conclusions from the results. 


\section{OCCUPATIONAL ACCIDENTS}

World Health Organization defines occupational accident as "an occurence arising out of or in the course of work which results in an occupational injury" (http://www.wpro.who.int/). International Labour Organization defines occupational accident as, "an occurence arising out of or in the course of work fatal occupational injury or non-fatal occupational injury" (http://www.oit.org/ilolex/ ). Occupational injury means death and personel injury or disease resulting from an occupational accident. Often the term occupational accident is understood as a sudden, external and involuntary event (Hamalianen et al., 2005;139). From the perspective of European Statistics on Accidents at Work (ESAW) occupational accidents are discrete occurence in the course of work, which leads to physical or mental harm" and the definition also includes accidents occuring during work but off the company's premises (Fernandez et all., 2009;193)

According to Turkish Social Security Law, an occupational accident occurs in one of the following situations or cases and harms the insured person physically or psychologically at that time or during the following period:

a) When the insured person is in the work place

b) Due to operations conducted by the employer

c) During the period in which the insured person spends his or her time without doing his/her actual work since he/she is sent to a different place by the employer.

d) During the time, given to insured women for breastfeeding.

e) Accidents which occur during the transportation of insured persons via a vehicle provided by the employer to and from the workplace.

In a study on the definition of occupational accident, Niza et al.,(2008) found that there are a number of different definitions in use, depending on the authors' scientific domain and nationality. The authors mentioned that the discrepancies in the definition and interpretation of what an occupational accident may obstruct an impressive communucation between workers, employers and governmental organizations. However, the common point in all definitions is that occupational accident is a type of accident in which the insured worker gets physically and/or mentally hurt by a sudden external cause while doing actual work under the supervision of the employer. In order to define an accident as an occupational accident, firstly the accident must be caused by an external factor and must occur in a very short time. The damage caused by the accident may affect the physical and/or mental health of the victim.Moreover, it is imperative that the event resulted in accident not be desired advertently by the victim (Demirbilek and Pazarlıoğlu, 2007; 81-82). 


\subsection{Causes of Occupational Accidents}

Occupational accidents occur lack of job safety training. Either employers simply do not want to spend resources in order to prevent occupational accidents or workers might be negligent, and have no sense of awareness, and also there might be no effective auditing (Unsar and Sut, 2009; 617). Occupational accidents which occured in Turkey in 2006 can be distributed by their causes as follows:

\section{Tablo1: Distribution of Occupational Accidents by Their Causes}

\begin{tabular}{|c|c|c|c|}
\hline Type of An Accident & Female & Male & Total \\
\hline Transportation Accidents & 171 & 2882 & 3053 \\
\hline Accidental Poisoning & 4 & 26 & 30 \\
\hline Falls of Persons & 545 & 8351 & 8896 \\
\hline Accident caused by machinery & 476 & 9057 & 9533 \\
\hline Accident caused by explosion & 22 & 642 & 664 \\
\hline $\begin{array}{l}\text { Exposure to or contact with extreme } \\
\text { tempratures }\end{array}$ & 80 & 1759 & 1839 \\
\hline Struck by falling objects & 452 & 16261 & 16713 \\
\hline $\begin{array}{l}\text { Stepping on, striking against or struck by objects } \\
\text { excluding falling objects }\end{array}$ & 1569 & 26877 & 28446 \\
\hline Exposure to or contact with electric current & 17 & 381 & 398 \\
\hline Injuries due to challenging of the body & 82 & 2.479 & 2.561 \\
\hline $\begin{array}{l}\text { Contamination of the part of the body with a } \\
\text { foreign object }\end{array}$ & 27 & 1136 & 1163 \\
\hline $\begin{array}{l}\text { Biting and kicking by animals, by poisonous } \\
\text { insect }\end{array}$ & 1 & 41 & 42 \\
\hline $\begin{array}{l}\text { Treatment accident and vaccination } \\
\text { complications }\end{array}$ & 0 & 0 & 0 \\
\hline $\begin{array}{l}\text { Late appearance of a problem because of an } \\
\text { earlier accident }\end{array}$ & 0 & 4 & 4 \\
\hline Accident while welding & 2 & 372 & 374 \\
\hline Murder and wound & 25 & 763 & 788 \\
\hline Trauma due to battle operation & 0 & 2 & 2 \\
\hline $\begin{array}{l}\text { Exposure to or contact with harmful substances } \\
\text { or radiations }\end{array}$ & 14 & 55 & 69 \\
\hline Other types of accident & 251 & 4200 & 4451 \\
\hline Unknown & 1 & 0 & 1 \\
\hline
\end{tabular}

\section{Source:}

http://www.sgk.gov.tr/sgkshared/sskdownloads/anasayfa/istatistik/istatistik2006/ 42006 ISKAZASI 16 45.xIs

As it is understood from the table, the most prominent factor inducing occupational accidents in 2006 is the "stepping on, striking against or struck by objects excluding falling objects" factor. This factor should be inspected carefully and the necessary precautions must be taken immediately. Hence, the cause of the occupational accident in our case study will be this particular factor. 
Furthermore, the causes of occupational accidents can be categorized in five behavioral groups, and a cause may be related to more than one group. The causes in question can be classified as follows (Esin, 2007;4):

a) Losing concentration

b) Unintentional faulty conduct (due to lack of necessary training, experience and/or failing to assses the critical situation)

c) Taking the easy way (usually appears as a result of the impetus of increasing the production)

d) Failing to obey the rules

e) Being affected by the environmental factors (lack of maintenance, disorder, system and machinery malfunction)

Figure 1: Economic Effects of Health and Safety At Company Level

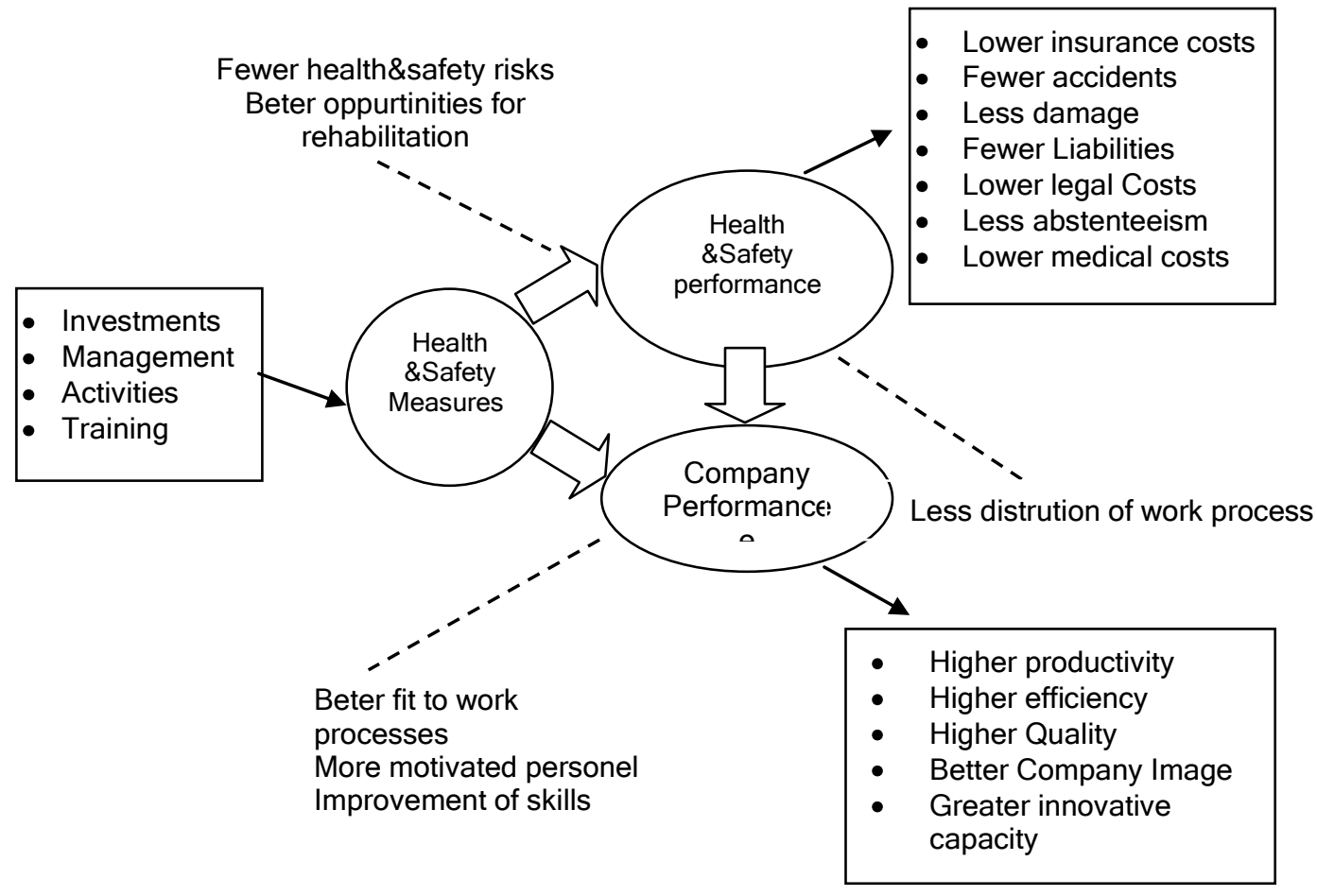

Source: (Muniz et al., 2008)

Management is the key factor in safety improvements, since it makes the decisions. Thus information about costs focuses on organization. We can see 
the the economic effects of occupational safety from a business perspective in the Figure 1 (Muniz et al.,2008;3)

It's in both the employers and employees' hands to control the factors. Employees should contribute to the management's efforts. The management must provide the necessary training and a safer work environment. Besides, they should ask these following questions to their firms:

- Have the training dossiers of the firm been examined by the top management and evaluated whether they are sufficient or not?

- How seriously are the ones who pass and fail the post-training tests distinguished from each other?

- Are the maintenance regulations really up to date and suitable for the machinery in use?

- To what extend are the machinery and the other equipment in secure?

- Are the special conditions of the personel who have a key role in firm's safety with their knowledge and experince being handled skillfully when downsizing or personnel transfer?

As it is understood from the figure, occupational accidents are not only interrupt the production process, generating, on the one hand, both financial and oppurtunity costs but also undermine the firm's international relatioship's and harm its public image.

\subsection{The Costs of Occupational Accidents}

The increase in occupational accidents in recent years together with the decrease in productivity has brought about direct and indirect costs for the firms. These costs can be resembled to an iceberg (Hamalainen et al., 2006; 138). The tip of the iceberg is direct costs and the big part under the water amounts to indirect costs. However, it is rather difficult to know what indirect costs consist of and how they are determined. Ünal et al.,(2008) have defined occupational accident costs in two categories with a generally accepted classification as visible(direct) and invisible (indirect) costs whereas Hamalianen et al.,(2006) have classified it as direct, indirect and hidden costs.

As it is understood from the explanations above, it is manifest that firms confront direct and indirect costs. The costs in question can be determined as follows (Yılmaz, 2002, http://www.isguvenligı.net ; Ünal et al., 2008;430):

\section{- Direct Costs}

- Medical Costs

- Compensation Costs

- Costs of Issue

- Social Insurance Contributions 
IMPLEMENTATION PROPOSAL FOR THE ASSESSMENT OF OCCUPATIONAL ACCIDENT COSTS IN TERMS OF QUALITY COSTS

- Maintenance and Repair Costs for Damaged Machinery

- Rehabilitation Costs

- Maintenance Costs of Victim's house

- Funeral Costs

- Other Costs (eg: Police, Fire Engine,Ambulance, Emergency and etc..)

- Indirect Costs

- Loss of Labor Force

$\checkmark$ Due to victim's inability to work

$\checkmark$ Due to first-aid given to injured person

$\checkmark$ Due to breaks taken by victim's colleagues.

$\checkmark$ Due to the time spent by the managers and the supervisors to the inspection of the accident.

$\checkmark$ Due to the reorganization and allocation of the occupation which the victim is responsible.

$\checkmark$ Due to the time spent in legal proceeding.

- Loss of Production

$\checkmark$ Due to the suspension of production because of accident

$\checkmark$ Due to breakdown of work schedule and work flow

$\checkmark$ Due to breakdown of machinery

$\checkmark$ Due to the damage in materials and raw materials.

$\checkmark$ Due to decraese in efficiency

- Losses of Being Behind on Orders

$\checkmark$ The firm's loss of reputation

$\checkmark$ Fine paid for overdue delivery

$\checkmark$ The Loss of the premiums for early delivery

Occupational accidents influence both human and financial loss. They create huge economic damage and harm to employees, firms and the national economy (society).

The most significant consequence of occupational accidents is that the employee loses his or her life. Nevertheless, even if occupational accidents do not result in death but injury, the employee can face with serious health issues. Furthermore, the victim may as well confront with temporary or permanent income losses and economic losses due to high amounts of medical care expenditures. In this respect, an employee who suffers an occupational accident is likely to need both financial aid for income loss and medical care for treatment. An employee who is unable to feed his family and needs other 
people's care may suffer from depression, psychological problems and deterioration in social relations. Moreover, a family whose member is killed in an occupational accident incurs financial loss as well as the pain felt for the loss. If the deceased employee has no social security, then the family is unable to obtain any support (Demirbilek and Pazarlığlu, 2007; 82-83).

Occupational accidents also cause losses of labor force and product. Interruption of the production process, the repairing and reorganizing efforts constitute the other losses. The costs generated by occupational accidents may differ in terms of the employer or the firm due to the business sector or the peculiarity of the incident. Occupational accidental costs affect national economy as well as the employer and employee. These accidents have a negative affect on the productivity of the national economy, they cause the loss of both labor force and work day. Workdays which are lost because of these accidents have reached a great extent all over the world. The economic loss and the loss of workdays in particular reduce the added-value that is created in Turkey and impede the socia economic development process.

\section{QUALITY COSTS}

Since the economic activity has become increasingly globalized, the measuring of quality costs have become very important particularly in such a competitive environment where developing countries are exposed to fierce competition (Miguel and Pontel, 2004;309).

The first attempt at a scientific approach to quality costs was made in the 1950s. It was Juran who brought out his perception about quality costs and he made it clear that quality cost is not the cost of running a quality department. His view was that there are costs that could be avoided at a reasonable expense and ones that it is economically inefficient to avoid (Halis and Oztas, 2002; 101)

Even though there are a good number of definitions as regards the term quality costs, as in social terms there is no consensus in a standard definition. Some define it as the necessary costs to obtain the quality, while others define it as the cost of quality department or the cost of bad quality. The definition "the cost of the bad quality" is commonly used (Koç and Demirhan, 2007; 88). Some of the definitions as regards quality costs are as follows:

$\checkmark$ According to British Standards Institution-BS 4778; quality-related costs are costs in ensuring and assuring quality as well as loss incurred when quality is not achieved (Koegh, 1994; 26).

$\checkmark$ Quality costs are the costs which emanate during the activities carried out in order to prevent flows, planned quality inspections and during the manufacturing of the product or ones that appear as a result of the defects detected after customer delivery (Yükçü, 1999; 90). 
$\checkmark$ Quality costs are associated with creation of quality, evaluation of coformance with quality, and the consequences of failure to meet requirements both within the factory and in the hands of customers (Feighenbaum, 1991; 110, Dalcı and Tanış, 2002, 136).

As it can be discerned from the definitions above, monitoring the quality costs inside the firm, is a higly important implementation which could make them more superior than their rivals. Since the succes of the firms is predicated on highly quality and low cost. When watched and evaluated thoroughly, the positive effects of quality costs can easily be seen. If a balance between the quality of the product and the costs is achieved, then the competitive force of the product will be increased. In order to establish the balance, it is required to watch and control the quality costs very closely. It is too important for the firm to collect the full and correct information concerning these costs in question in order that the firm can make reasonable decisions in terms of quality management.

Quality costs are used by the management in the area of quality improvement, customer satisfaction, market share and profit enhancment. It is the common economic denominator that forms the basic data for Total Quality Management. When quality costs are too great, it is a sign of management ineffectiveness and that can affect the organization's competitive position (Besterfiel et all., 1995; 107).

The cost of manufacturing a quality product by all means must be carefully managed in order to receive desirable long-term effect on the organization. The principal goal of the management is to create a competitive product or service bases on a balance between quality and cost factors. This goal may as well be supported by the analysis of quality costs which is a prominent management tool. For this reason, the analysis of quality costs is a significant management tool that provides (Oakland, 2000; 128):

- A method of assesing the effectiveness of the management of quality,

- A means of determining problem areas, opportunities, savings and action priorities.

\subsection{Need of Quality Costs Control}

Establishing a quality cost system is a beneficial effort that incurs financial and mental burdens. The benefits of the quality cost system can be summerized as follows (Roden and Dale, 2000; 179, Yükçü, 1999; 115-117):

- The level of quality of goods and services improves.

- Material costs and labor can be saved.

- Productivity and the product reliability maximize.

- Quality data are more readily accepted because they are collected and analysed with the accounting department in a team environment. 
- The quality control system helps the evaluation of capital investment alternatives.

- The quality control system helps justify and steer investments in prevention activities, which reduces quality costs. It also helps jusify and steer other quality improvement efforts and investments.

- The quality control system leads to the development of an advanced performance measure in the areas of customer satisfaction, production and design to better target indirect quality costs.

- Return on investment and sales are developed while reducing costs.

- When maintenance and repairment needed, purchasing additional equipment and materials can be considered more rationally.

The pitfalls of the quality system can be summerized as follows (Çabuk, 2005; 6-7):

- The allocation of factory overheads on calculation of quality costs is a debatable subject. In practice, some of the firms add the labor costs and raw material costs to the expenditures whereas a good number of firms do not do this application that way.

- Most quality costs evaluation systems in use are not suitable for depicting the quality costs of the sources such as divisions, products, designs, processes, vendors, distribution channels, regions and etc. For this reason, the quality cost data acquired from these systems can not be used in defining the place where the chances of quality improvement exist.

- Even if it is easily to determine the proportion of labor costs in quality costs, there is always lack of information concerning factory overheads.

There are two established quality costing models that are described in British Standard BS 6143:"Guide to The Economics of Quality (1992). The first one is the prevention-appraisal-failure (PAF) model put forward by Armand Feigenbaum in 1956 in the Harward Business Review, which Plunkett and Dale describe as "Almost universally accepted. The second one is the processing model, first used by Marsh for quality costing, which is advocated as being more in line with the philosophies underlying TQM. The essence of this model is that it can be used to measure the total cost associated with any process. It allocates costs to categories of conformance and non-conformance (Bland et all., 1998,367, Cited in Goulden ve Rawlings, 1997;200,).

Although there are several methods that can be used for collecting quality costs and establishing a quality costing system, all of the classification methods are similiar in nature. For example, the price of conformance can be represented by prevention and appraisal, and the price of non-conformance by failures (Miguel and Pontel, 2004; 309). 
Tablo 2: Types of Quality Costs

\begin{tabular}{|c|c|}
\hline Quality Costs & Types of Quality Costs \\
\hline Prevention Costs & $\begin{array}{l}\text { - } \quad \text { Quality Planning } \\
\text { Design and Development of } \\
\text { Quality Measurement and Test } \\
\text { Equipment } \\
\text { Quality Review and Verification } \\
\text { of Design } \\
\text { Calibration and Maintenance of } \\
\text { Quality Measurement and Test } \\
\text { Equipment } \\
\text { Calibration and Maintenance of } \\
\text { Production Equipment Used to } \\
\text { Evaluate Quality } \\
\text { - Supplier Assurance } \\
\text { - } \text { Quality Training } \\
\text { - } \text { Quality Auditing } \\
\text { Acquisition Analysis } \\
\text { Reporting of Quality Data } \\
\text { Quality Improvement Programs }\end{array}$ \\
\hline Appraisal Costs & $\begin{array}{ll}\text { - } & \text { Pre-Production Verification } \\
\text { - } & \text { Receiving Inspection } \\
\text { - } & \text { Laboratory Acceptance Testing } \\
\text { - } & \text { Inspection and Testing } \\
\text { - } & \text { Inspection and Test Equipment } \\
\text { - } & \text { Materials Consumed During } \\
& \text { Inspection and Testing } \\
\text { - } & \text { Analysis and Reporting of Test } \\
& \text { and Inspection Results } \\
\text { - } & \text { Field Performance Testing } \\
\text { - } & \text { Approvals and Endorsements } \\
\text { - } & \text { Inventory Evaluation } \\
-\quad & \text { Record Storage } \\
\end{array}$ \\
\hline Internal Failure Costs & $\begin{array}{lll}- & \text { Scrap } \\
- & \text { Replacement Rework and Repair } \\
\text { - } & \text { Troubleshooting or Defect/Failure } \\
& \text { Analysis } \\
\text { - } & \text { Reinspection and Retesting } \\
\text { - } & \text { Fault of Subcontractor } \\
\text { - } & \text { Modification Permits and } \\
& \text { Concessions } \\
\text { - } & \text { Downgrading } \\
\text { - } & \text { Downtime }\end{array}$ \\
\hline External Failure Costs & $\begin{array}{ll} & \text { Complaints } \\
- & \text { Warranty Claims } \\
- & \text { Products Rejected and Returned } \\
- & \text { Concessions } \\
- & \text { Loss of Sales } \\
- & \text { Recall Costs } \\
-\quad & \text { Product Liability } \\
\end{array}$ \\
\hline
\end{tabular}

Source: BS 6143, Part 2; Yukçü, 2006; 155-163; Yükçü, 1999; 93-108. 


\section{Süleyman YÜKÇÜ and Seçkin GÖNEN}

Categorization of costs need not necessarily be restricted to those of the two above mentioned models. Organizations can also consider other forms of categorization which will suit their business needs (Bland et all., 1998:368). But in this paper, quality costs will be covered with respect to PAF model. According to British Standard BS 6143:"Guide to The Economics of Quality (1992), The PAF model identifies the costs associated with three categories of quality related activities as prevention, appraisal and failure. The last category can be further divided into internal and external failure. Table 2 indicates these categories and types of types of quality costs.

Prevention costs are the costs of any action taken to prevent or reduce the future risk of non-conformity, eg. the costs of implementing a quality system and employing a quality manager/department. Appraisal costs are the cost of evaluating the achievement of quality, including inspection, testing and quality audit. Internal failure costs are the cost arising within an organization due to non-conformities or defects, such as scrap, rework and redesign. External failure cost is the cost arising after delivery to a customer/user due to nonconformities or defects, such as the cost of claims against warranty, replacement and lost orders.

This paper states that accidental costs could be regarded as failure costs and thus as quality costs in compliance with the definitions of British Standard 6143. Figure 2 indicates the relationship between occupational accidental costs and quality costs. 
Figure 2: The Relationship Between Quality Costs and Occupational Accidental Costs

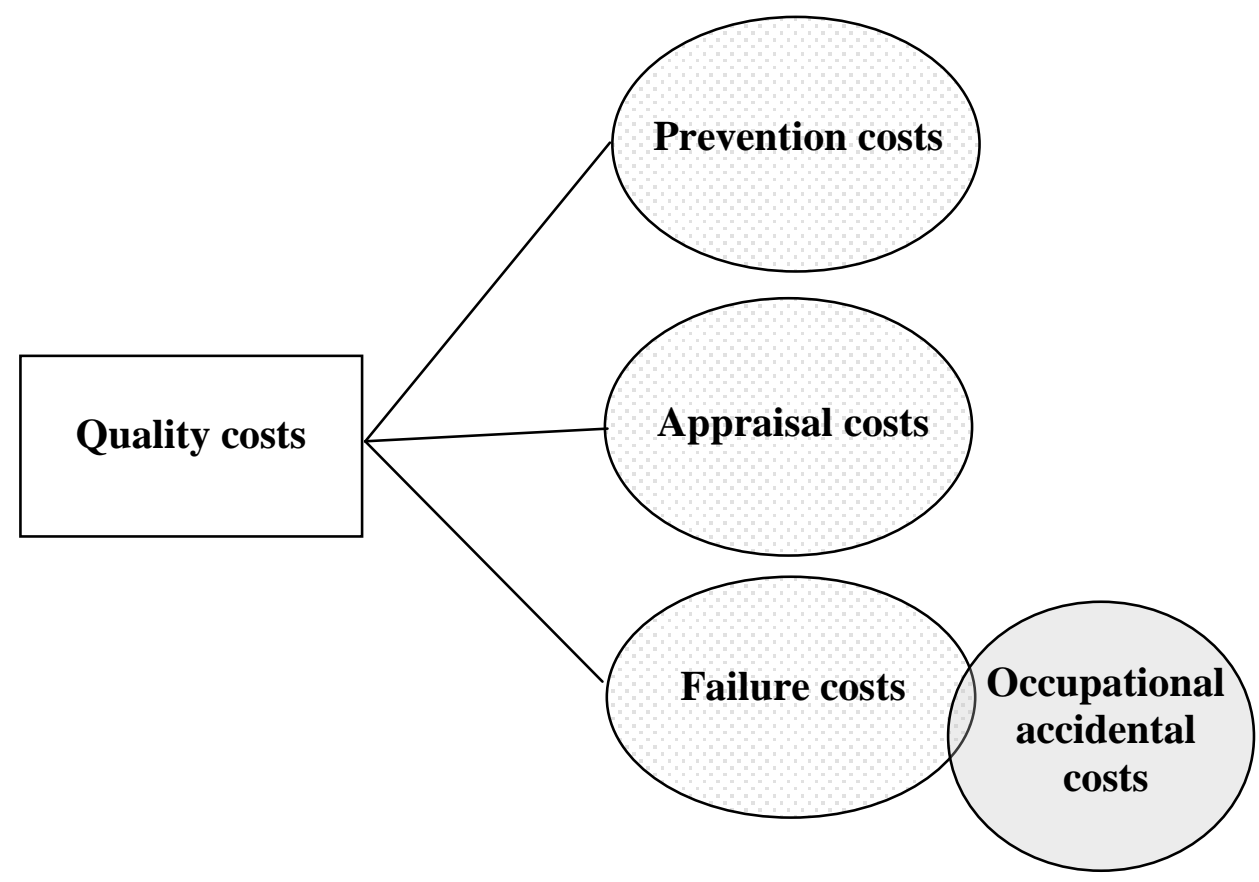

In this paper, only the quality costs which are in relation to occupational accidents are explained. They are explained as follows:

- Quality Planning: Quality planning is the action for quality systems planning and determining an established standard that fulfills both desirable product design and the customer's expectations in terms of quality. This includes quality planning, inspection planning, reliability planning and all the other actions appropriately composing other necessary plannings.

- Calibration and Maintenance of Quality Measurement and Test Equipment: These are the maintenance and measurement cost of machinery, stable goods ve similiar equipments.

- Quality Training: This includes a number of costs that are related to participation, program, development, application, execution and fixation costs concerning the quality training programs.

- Quality Auditing: This includes all costs pertinent to the assesment and auditing of the whole quality control system or the special parts. 
- Acquisition Analysis and Reporting of Quality Data: Costs which are relevant to processing and analysis of the data in order to prevent the failure that may show up in the future must be included in this item.

- Quality Improvement Programs: This includes raising awareness of the workforce (at all levels) coupled with monitoring for signs of improvement.

- Pre-Production Verification: These are pre-production testing and measurement costs for the purpose of determining the suitability between the product desing and the quality requirements.

- Receiving Inspection: All testing and inspecton costs of the units, parts, materials and raw materials are included in this item.

- Laboratory Acceptance Testing: These costs are related to tests provided by the laboratory personel to evaluate the quality of raw materials.

- Inspection and Test Equipment: These are the costs of depreciation and working costs of the equipment.

- Field Performance Testing: These are the costs that are performed probable user environment. User environment can be the place where the users receive the product, his/her house or workplace. This type of the costs comes up before the user receives the product.

- Downtime: These are the costs that are caused by the use of time unnecessarily.

- Complaints: These are the costs which should be logged and investigated to prevent recurrence.

- Recall costs: These are the costs that can be charged against the supplier and may include other charges as well as shipping costs.

\section{RESEARCH STUDY}

A study of application has been carried out and several assesments has been put forth in order to support that data regarding occupational accidents and quality costs. 


\subsection{The Objective, Method and Limitations of the Research}

The objective of our study is to assses the costs of occupational accidents in terms of quality costs and to give information concerning necessary measures. For this purpose, a study has been performed in a firm which operates in a marble industry and is located in Denizli. When the method of research is selected, taking into account similiar applications in academic studies, the literature was scanned initially and one of the leading research methods, "The Case Study" has been adopted. At the first level of our application, the firm was visited and it was arranged an interview with the proprieter of the firm. During the interview, information regarding the research was presented and subsequently the purpose and the method of the study were explained in detail. In order to achieve a more effective exchange of opinions and to provide relevant information in respect of the subject studied, the interview was carried out with thr questions that were prepared beforehand.

In our study, since we are of the opinion that to carry out the research in more than one firm would be ineffective and very unlikely to give meaningful comparison, we found it more suitable to carry out a more elaborate study in a single firm. Another probable approach for this research could be carrying out an application with the help of a questionairre. However, since the possible reactions of the interviewers' such as resisting, chosing not to comment or giving unreal answers, such method would not produce healty results.

\subsection{The Acquaint of the Firm}

This firm is a travertine (marble) manufacturer and exporter located in Denizli where one of the most dynamique and outstanding cities of Turkey is in 2001. The factory is operated on $7.200 \mathrm{~m}^{2}$ covered and $27.000 \mathrm{~m}^{2}$ open area with an annual production capacity of $300.000 \mathrm{~m}^{2}$. The marble processed in the factory are exported to USA, together wih various countries in the world such as Canada, United Kingdom, New Zeland, Italy, Spain and Australia. The execution level of the firm consists of administrative manager, production managers and shift managers. There are eighty one personel currently working in the factory. The distribution of the personel is depicted below:

- 1 Administrative Manager (Director)

- 5 Production Manager

- 5 Shift Manager

- 70 Qualified and Non-Qualified Workers

The monthly revenue of the firm is approximately $600.000 \mathrm{TL}$. A total of 80.000 $T L$ is being paid to workers in a month. Every worker has the documents such as medical service contract and heavy and dangerous duty eligibility certificate in their personal files. 


\subsection{Case Study}

Mining technician Hasan Sentuna was the production manager in the cutting department of a travertine (marble) factory. On 22nd September, 2007, a day in the Holy Month of Ramadan, he was fasting. On the 08:00-16:00 shift at 14:30, he climbed to the roof to supervise maintenance worker Yüksel Deniz, who was trying to hitch sunshades on the roof. Mr. Sentuna disregarded the warnings from witnesses and climbed of his own accord. Mr. Deniz stated that there was no need to climb up and the job was finished, however Mr. Sentuna wanted to see the work done. After the job was finished, Mr. Deniz headed to the stairs and Mr. Sentuna followed him. While they were climbing down one right after the other, Mr. Sentuna lost his balance and fell down onto the translucent lightning panel. The panel broke off, and Mr. Sentuna fell down and hit to the concrete floor right beside the filling machine in the tile production department. Mr. Deniz, staring the scene from the broken part of the lightning panel, saw him lying down the floor and blood spilling from his mouth. Mr. Deniz was hurried to climb down to reach Mr. Sentuna. Due to the fact that the bleeding was not stopped, Mr. Deniz and other workers took Mr. Sentuna to a hospital by factory's car without waiting the ambulance. All the necessary medical attention was given, however Mr. Sentuna passed away.

After the tragic event, the factory stopped its activities for two days. Temporal and spiritual duties required by traditions and religion were carried out. Employer, who also was the facility manager, did not take any legal actions against the deceased. He also proposed reconciliation to the deceased's family. To settle the reconciliation, legal representatives of employer have had a few face to face meeting with the wife and other family members of the Mr. Sentuna. Employer offered an apartment worth $70.000 \mathrm{TL}$ so as to share the pain of family and help them to avoid paying rent anymore. He also offered a position to the wife of Mr. Sentuna, who is a geology engineer and experienced in the marble sector. However she rejected the position and demanded an apartment of $150.000 \mathrm{TL}$ value. Upon this, employer offered to pay their house rent until the reconciliation settled, and paid two months in cash. However, Mr. Sentuna's wife considered all these actions as "distraction", took the case to the court, and legal procedures began.

\subsection{Failure Costs in Occupational Accidents}

The cost of occupational accident taking place in the factory is calculated approximately as 150.850 TL.The allocation of the cost is listed in the Table below:

As it is listed below, in additon to direct and indirect costs, there appear other costs that can not be measued such as loss of production and loss of efficiency. Moreover the cost regarded as failure costs (Table 3) can be viewed as alternative costs to the lost of reputation and company image due to the possible legal claims and court procedures 
Table 3: Details Of Failure Costs

\begin{tabular}{|c|c|c|}
\hline Quality Costs & Details & Total (150.850 TL) \\
\hline Complaints & Medical Costs & $750 \mathrm{TL}$ \\
\hline Complaints & Compensation Costs & $35.000 \mathrm{TL}$ \\
\hline Complaints & Costs Of Issue & $600 \mathrm{TL}$ \\
\hline Recall Costs & $\begin{array}{c}\text { Costs of Police, } \\
\text { Transportation and } \\
\text { Emergency }\end{array}$ & $2.000 \mathrm{TL}$ \\
\hline Recall Costs & $\begin{array}{c}\text { Rent Expenses (2 months) } \\
\text { Cost of Visitation }\end{array}$ & $2.000 \mathrm{TL}$ \\
\hline Recall Costs & $\begin{array}{c}\text { Wage Cost for 2-day-work } \\
\text { loss. }\end{array}$ & $10.000 \mathrm{TL}$ \\
\hline Recall Costs & $\begin{array}{c}\text { Depreciation Costs for 2- } \\
\text { day-work loss. }\end{array}$ & $5.000 \mathrm{TL}$ \\
\hline Downtime & Downtime &
\end{tabular}

\subsection{Anticipation of Activities Preventing Occupational Accidents and its Costs}

It is possible to asses the activities against occupational accidents and its costs as "prevention costs and appraisal costs in the firm where the application is carried out.

The information regarding the assesment in terms of prevention costs can be listed as follows:

- Quality Planning: The work performed in the factory is categorized as heavy and dangerous duty. Thus, it is obligatory that, security measures be taken and working conditions be made more secure. Provided that necessary safety conditions are taken while performing the job as in having experienced roofing workers, safety at work can be established. It is estimated that if quality planning and work processes had been carried out in the factory, it would have been clearly stated who had been authorized to 
work on the roof. Those plans could have included conditions such as using workers who are not fasting during Ramadan when performing chores carrying higher risks. Some chores might also be postponed during Ramadan and assigned at a later time.

- Calibration and Maintenance of Quality Measurement and Test Equipment: This includes the maintenance and calibration costs of the equipments used for quality measurements.

- Quality Training: The incident in the factory indicates that the victim's decision to climb up the roof even if it is not in his responsibility manifests that he failed to follow the regulations concerning his duty. Despite the fact that Mr.Sentuna had a training sertificate, the training has not been carried out periodically. The participation in training programs comprises a number of costs including application, execution and organization of the program.

- Quality Auditing: It is understood that the management did not perform auditing effectively in order to provide safe and secure work environment.

- Acquisition Analysis and Reporting of Quality Data: The prevention activities can be monitored and filed as reports.

- Quality Improvement Programs: Programs which pay to improve labor quality, information and skill can be developed and implemented. Trainings which help improve the assesment and decision-making abilities of employees, in addition, sportive activities can be supported.

The information regarding the assesment in terms of appraisal costs can be listed as follows:

- Pre-Production Verification: New employees can operate in similiar but less dangerous machines in order to gain experince before performing their actual work.

- Receiving Inspection and Laboratory Acceptance Testing: Several tests measuring the employee's eligibility for the job, or the reaction to heavier of more dangerous chores. Employees consuming a good amount of alcohol, being overweight, having weak reflexes may not be employed.

- Inspection and Test Equipment: Assesment, perception and agility abilities of the employees performing risky jobs such as marble production can be inspected periodically or the cost of test equipment may provide quality.

- Field Performance Testing: Factory workers can be asked whether they perform their chores in another place other than their work place or whether 
they can meet the risk factor in marble cutting while the marble is assembled.

\section{CONCLUSION}

The importance of occupational accidents has increased worldwide, since fatal accidents occur and they create significant amount of costs which affect the worker, the employer, the national economy and society. It is manifest that the calculation of financial loss induced by occupational accidents is a prominent factor for prevention. The lost values may cause permanet loss for the firms. It is possible to approach to the subject from the point of quality costs and reduce or eradicate incidents completely with several prevention and appraisal costs. These costs induced by prevention and appraisal costs may be less than the costs appearing as a result of occupational accident.

This study represents an attempt to show the relationship between occupational accidents and quality costs. In the research part of our study, it is calculated that the failure costs induced by occupational accident is approximately $150.850 \mathrm{TL}$. Nevertheless, a tangible calculation could not be made in respect of prevention and appraisal costs, since these costs were not dealt. This study contributes to literature in the sense that occupational accidents that may produce highly excessive costs can be prevented by executing a good number of prevention activities if the costs are measured.

\section{REFERENCES}

AĞAR, A. (2009), "iş Kazası ve Meslek Hastalığının; Unsurları, Tanımı ve Bildirim Süreleri”, İşveren Dergisi, 47(4):81-86.

BESTERFIELD, D.; MICHNA, C.; BESTERFIELD, G and SACRE, M. (1995): Total Quality Management, Prentice Hall, USA.

BLAND, M., MAYNARD, J and HERBERT, D. (1998):"Quality Costing of An Administrative Process", The TQM Magazine, 10(5):367-377.

BSI 6143- Part 2: British Standard Institution (1992), Guide to The Economics Of Quality: Prevention, Appraisal and Failure Model, London.

ÇABUK, Y. (2005):"Kalite Maliyetleri ve Kalite Maliyetlerini Ölçmeden Kullanılan Yöntemler”, ZKU Bartın Orman Fakültesi Dergisi, 7(7):1-8.

DALCI, I and TANIŞ, V. (2002): "Quality Costs and Their Importance In Cost And Management Accounting", Çukurova Üniversitesi Sosyal Bilimler Enstitüsü Dergisi, 10(10):1134-147. 
DEMIRBiLEK, S and PAZARLIOĞLU, V. (2007): "Türkiye'de İş Kazalarının Oluşumunda Etkili Olan Faktörler: Ampirik Bir Uygulama”, Finans Politik\&Ekonomik Yorumlar, 44(509):81-91.

ESIN, A. (2007): "İ̧ Kazalarına Değişik Yaklaşım-Davranışsal Güvenlik", Mühendis ve Makine Dergisi, 48(567):3-9.

FEIGENBAUM, A. (1991): The Total Quality Control, McGraw-Hill, USA.

FERNANDEZ, S, RIOS, I., CAZORLA, A and FALERO, E. (2009), "Pilot Study On The Influence Of Stress Caused By The Need to Combine Work and Family On Occupational Accidents In Working Women", Safety Science, No.47:192198.

GOULDEN, C and RAWLINS, L. (1997): "Quality Costing: The Application of The Process Model within a Manufacturing Environment", International Journal of Operations\&Production Management, 17(2):199-210.

HALIS, M and OZTAS, A. (2002): "Quality Cost Analysis in ISO-9000-Certified Turkish Companies", Managerial Auditing Journal, 17(1):101-104.

HAMALAINEN, P, TAKALA, J and SAARELA, K. (2006), "Global Estimates Of Occupational Accidents", Safety Science, No.44:137-156.

http://www.oit.org/ilolex/cgi-lex/convde.pl?P155

http://www.sgk.gov.tr/sgkshared/sskdownloads/anasayfa/istatistik/istatistik2006/ 42006 ISKAZASI 16 45.x/s (17/02/2009)

http://www.wpro.who.int/NR/rdonlyres/EFD3A0FD-E836-4C13-BA045614011BDE25/0/35definitions.pdf (18/02/2009)

KEOGH, W. (1994): "The Role of the Quality Assurance Professional in Determining Quality Costs", Managerial Auditing Journal, 9(4):23-32.

KOÇ,T and DEMIRHAN, O. (2007): "Önleme Ve Değerlendirme Maliyetleri ile Uygunsuzluk Maliyeti Arasındaki İlişkinin Analizi“, İstanbul Ticaret Üniversitesi Fen Bilimleri Dergisi, 6(11):87-97.

MIGUEL, P and PONTEL, S. (2004): "Assesing Quality Costs of External Failures (Warranty Claims)", International Journal Of Quality\&Reliability Management, 21(3):309-318.

MUNIZ, B., PEON, J and ORDAS, C. (2008): "Relation Between Occupational Safety Management and Firm Performance", Safety Science:1-12. 
NIZA, C., SILVA, S and LIMA, M. (2008): "Occupational Accident Experince: Association with Workers' Accident Explanation and Definition", Safety Science, No.46:959-971.

OAKLAND, J. (2000): Total Quality Management: Text with Cases, Butterworth, Heinemann, London.

PLUNKETT, J. And DALE, B. (1987), "A Review of The Literature on Quality Related Costs", International Journal of Operations\&Production Management, 4 (1):40-52.

RODEN, S and DALE, B. (2000):"Understanding the Language of Quality Costing", The TQM Magazine, 12(3):179-185.

ÜNAL, G., YAMAN, K and GÖK, A. (2008): "Türkiye'de Tarımsal İş Kazaları ve Meslek Hastalıklarının Maliyeti Üzerine Bir Araştırma", Tarım Bilimleri Dergisi, 14(4):428-435.

UNSAR, S and SUT, N. (2009): "General Assesment of The Occupational Accidents That Occured In Turkey Between The Years 2000-2005", Safety Science, No.47:614-619.

YILMAZ, G (2002):"Iş Kazalarının Maliyeti", http://www.isguvenligi.net $(15 / 01 / 2009)$

YÜKÇÜ, S. (1999): Kalite Maliyetlerinin Muhasebeleştirilmesi (Kalite Muhasebesi), Anadolu Matbaacılık,Izmir.

YÜKÇÜ, S. (2006): "Kalite Maliyetleri Muhasebesi", Türkiye Maliyet ve Yönetim Muhasebesi Sempozyumu, Kocaeli:155-174. 